Laws, Theories, and Patterns in Ecology 



\section{Laws, Theories, and Patterns in Ecology}

Walter K. Dodds

田

UNIVERSITY OF CALIFORNIA PRESS

Berkeley Los Angeles London 
University of California Press, one of the most distinguished university presses in the United States, enriches lives around the world by advancing scholarship in the humanities, social sciences, and natural sciences. Its activities are supported by the UC Press Foundation and by philanthropic contributions from individuals and institutions. For more information, visit www.ucpress.edu.

University of California Press

Berkeley and Los Angeles, California

University of California Press, Ltd.

London, England

C) 2009 by The Regents of the University of California

Library of Congress Cataloging-in-Publication Data

Dodds, Walter Kennedy, 1958-

Laws, theories, and patterns in ecology / Walter K. Dodds.

p. $\mathrm{cm}$.

Includes bibliographical references and index.

ISBN 978-0-520-26040-5 (case : alk. paper)-ISBN 978-0-520-26041-2

(pbk. : alk. paper) 1. Biotic communities. 2. Ecology-Philosophy.

I. Title.

QH541.D64 2009

$577-\mathrm{dc} 22$

2009010052

Manufactured in The United States of America

$\begin{array}{llllllll}16 & 15 & 14 & 13 & 12 & 11 & 10 & 09\end{array}$

$\begin{array}{llllllllll}10 & 9 & 8 & 7 & 6 & 5 & 4 & 3 & 2 & 1\end{array}$

The paper used in this publication meets the minimum requirements of ANSI/NISO Z39.48-1992 (R 1997)

(Permanence of Paper). $\infty$ 
For the Ecologists 
